УДК 004.72:531.7.08

DOI https://doi.org/10.32689/maup.it.2021.2.1

\title{
Андрій ДУДНІк
}

кандидат технічних наук, доцент, професор кафедри комп'ютерних інформаційних систем і технологій, ПрАТ «ВНЗ «Міжрегіональна Академія управління персоналом», вул. Фрометівська 2, Київ, Україна, індекс 03039 (a.s.dudnik@gmail.com)

ORCID: https://orcid.org/0000-0001-5725-5942

\section{Andrey DUDNIK}

Candidate of Technical Sciences, Associate Professor, Professor at the Department of Computer Information Systems and Technologies, Interregional Academy of personnel management, 2 Frometivska Street, Kyiv, Ukraine, postal code 03039 (a.s.dudnik@gmail.com)

Бібліографічний опис статті: Дудник А. Моделі та методи підвищення продуктивності безпроводових мереж у складі комп'ютеризованих систем вимірювання механічних величин. Інформаційні технології та суспільство. 2021. Вип. 2. С. 6-14. DOI: https://doi.org/10.32689/maup. it.2021.2.1

Bibliographic description of the article: Dudnik, A. (2021). Modeli ta metody pidvyshchennia produktyvnosti bezprovodovykh merezh u skladi kompiuteryzovanykh system vymiriuvannia mekhanichnykh velychyn [Models and methods of growth of productivity of safety networks in components of computerized systems of measurement of mechanical quantities]. Informatsiini tekhnolohii ta suspilstvo - Information technology and society, 2, 6-14. DOI: https://doi.org/10.32689/maup.it.2021.2.1

\section{МОДЕЛІ ТА МЕТОДИ ПІДВИЩЕННЯ ПРОДУКТИВНОСТІ БЕЗПРОВОДОВИХ МЕРЕЖ У СКЛАДІ КОМП'ЮТЕРИЗОВАНИХ СИСТЕМ ВИМІРЮВАННЯ МЕХАНІЧНИХ ВЕЛИЧИН}

Анотація. Стаття присвячена моделям та методам підвищення продуктивності безпроводових сенсорних мереж, що перебувають у складі комп'ютеризованих систем вимірювання механічних величин, побудованих на основі декомпозищії нижніх рівнів еталонної моделі OSI. Запропоновано метод підвищення продуктивності мереж, що функціонально об'єднує фізичний та мережевий рівні, що покращує їі ефективність в зонах невпевненого прийому майже в два рази. Розроблено модель структурної схеми пристрою підвищення якості передавання даних в зонах невпевненого прийому або з недостатньою завадостійкістю, що базується на основі так званого методу моніторингу стану якості зв'язку.

Ключові слова: безпроводова мережа, механічні величини, сенсор, продуктивність, сигнал, комп'ютеризована система вимірювання, інформаційно-вимірювальна система.

\section{MODELS AND METHODS OF GROWTH OF PRODUCTIVITY OF SAFETY NETWORKS IN COMPONENTS OF COMPUTERIZED SYSTEMS OF MEASUREMENT OF MECHANICAL QUANTITIES}

Abstract. The article is devoted to models and methods of improving the productivity of wireless sensor networks, which are part of computerized systems for measuring mechanical quantities, based on the decomposition of the lower levels of the reference model OSI. The method of increasing the productivity of networks is proposed, which functionally combines physical and network levels, which improves its efficiency in zones of uncertain reception almost twice. The model of the structural scheme of the device for increasing the quality of data transmission in zones of uncertain reception or with insufficient noise immunity, based on the so-called method of monitoring the quality of communication, is developed.

Key words: wireless network, mechanical values, sensor, performance, signal, computerized measurement system, information and measuring system.

Вступ. Серед різноманітних класів комп'ютерних інформаційних систем і мереж особливе місце займають системи і мережі, транспортна служба яких побудована на використанні радіоефіру в якості середовища передачі даних комп'ютеризованих систем вимірювання механічних величин (безпроводові сенсорні мережі). Тому при створення наукових основ побудови комп'ютеризованих систем вимірювання механічних величин, важливе місце займає продуктивність безпроводових сенсорних мереж на основі модифікації існуючої класичної еталонної моделі взаємодії відкритих систем (EM OSI/ISO), згідно з якою проектуються, створюються і експлуатуються більшість засобів передачі даних інформаційно-вимірювальних систем, а також теоретичний аналіз та пошук оптимальних методів моделювання, взаємодії та управління комп'ютеризованих систем вимірювання механічних величин. Питанням дослідження інформаційно-вимірювальних систем, в тому числі і дослідженням технологій моделювання, управління і взаємодії комп'ютеризованих систем вимірювання механічних величин, присвячено 
роботи сучасних вчених Кваснікова В.П., Орнадського Д.П., Осмоловського А.І., а також роботи Геєра Д., Ірвіна Дж., Ліері Дж., Рошана П., Столлінгса В., Харля Д. та ін.

Постановка задачі. Метою даного дослідження $є$ аналіз та обгрунтування теоретичних основ, а також розробка моделей та методів, пов'язаних з підвищенням продуктивності безпроводових мереж, що входять до складу комп'ютеризованих систем вимірювання механічних величин.

Виклад основного матеріалу. Проведено порівняльний аналіз основних існуючих технологій передавання показників вимірювання. На основі експериментальних досліджень виявлено недоліки та ступені свободи для покращення систем управління, взаємодії та підвищення продуктивності в існуючих технологіях безпроводового передавання даних інформаційно-вимірювальних систем. Розглянуто моделі безпроводових комп'ютеризованих систем вимірювання механічних величин та особливості моделювання передачі показників вимірювання у безпроводовому середовищі [1-5].

Багатопроменевий характер поширення радіохвиль, коли кожна точка простору характеризується тим, що до неї надходять сигнали з різних напрямків та з різними часовими затримками, спливає багатократній інтерференції сигналів та їх суттєвому спотворенню. Такі спотворення мають суттєвий вплив на характеристики системи, якщо тривалість затримки перевищує тривалість передавання пакету даних вимірювання. Тобто, у комп'ютерних системах безпроводового зв'язку, як і для проводових систем, велике значення має головне правило, згідно з яким пакет повинний досягти кінцевої точки раніше, ніж буде переданий останній його символ. Але у разі різнонаправленого поширення безпроводових сигналів виконати цю умову значно важче [1-5].

Концептуальна модель простого варіанту мережі скатернет (розподіленої мережі з багатьма розгалуженнями на основі технології Bluetooth), що входить до складу комп'ютеризованої системи вимірювальної системи, представлена відкритою (незамкнутою) багатофазною системою масового обслуговування. 3 погляду класифікації еталонної моделі описувалися два нижні рівні. Транзакт, що $є$ неподільним об'єктом в системі імітаційного моделювання загального призначення, породжувався бітом, що переміщується в скатернет від джерела інформації до споживача. Кожна фаза моделювалася СМO G/M/n з відмовами і дисципліною FIFO. Універсальна система імітаційного моделювання забезпечує збір і статистичну обробку даних про транзакти, затримані в кожній точці моделі, а також інтенсивності потоків відмов. Час затримки бітів в каналах передавання (Wчерги) даної мережі визначається у відповідності до формули для обчислення часу затримки в черзі багатоканального пристрою з очікуванням:

$$
W_{\text {черги }}=\frac{1}{\sum_{i=1}^{N} \lambda_{i}} L_{\text {черги }}
$$

де $\lambda$ - інтенсивність надходження бітів, що передаються для $i$-го стану;

Lчерги - середня кількість бітів, що передаються і визначається за наступною формулою:

$$
L_{\text {черги }}=\frac{\sum_{i=1}^{N} \rho_{i}{ }^{n+1} P_{0}}{n \cdot n !\left(1-\sum_{i=1}^{N} \rho_{i} / n\right)^{2}},
$$

де $n$ - кількість розподілених підканалів безпроводового передавання даних мережі Bluetooth, що для даного випадку складає 23 підканали;

$P_{0}$ - імовірність того, що підканал на даний момент зайнятий, визначається за формулою:

$$
P_{0}=\left(1+\frac{\sum_{i=1}^{N} \rho_{i}}{1 !}+\frac{\sum_{i=1}^{N} \rho_{i}}{2 !}+\ldots+\frac{\sum_{i=1}^{N} \rho_{i}^{n}}{n !}+\frac{\sum_{i=1}^{N} \rho_{i}^{n+1}}{n !\left(n-\sum_{i=1}^{N} \rho_{i}\right)}\right)^{-1},
$$

де $\rho$ - навантаження на дану мережу безпроводового передавання даних, що визначається за формулою:

$$
\rho=\frac{\sum_{i=1}^{N} \lambda_{i}}{\mu},
$$

де $\lambda$ - інтенсивність надходження бітів до мережі передавання даних при і-тому стані; 
$\mu$ - інтенсивність обслуговування бітів у мережі передавання даних. Підставивши усі ці значення у формулу (1), отримаємо наступну результуючу формулу:

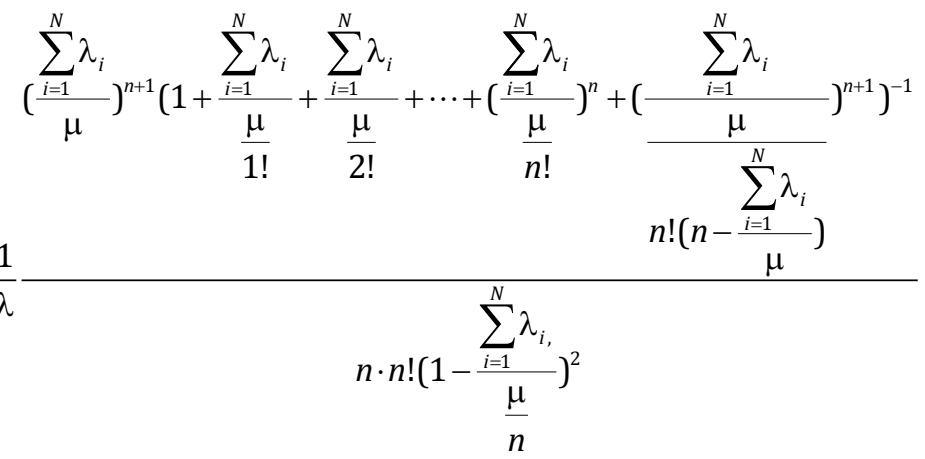

Головний пристрій “Master" передає біти в непарні моменти часу, а підлеглий пристрій “Slave” - у парні. Дана модель має ієрархічну будову адже пристрій, який для окремої ділянки мережі $\epsilon$ головним, для іншої ділянки може бути підлеглим. Експериментальне дослідження даної моделі було проведене за допомогою інструментального засобу GPSS, при $10^{6}$ прогонів. 3 отриманих результатів виявлено, що співвідношення часу затримки відповідає реально наявним співвідношенням параметрів мережі [6].

Розглянута модель інфрачервоного трафіку. Мета даного дослідження - побудова одноканальної моделі безпроводовго передавання параметрів вимірювання інфрачервоної сенсорної мережі, результати роботи якої б відображали часові та кількісні параметри передавання даних вимірювання механічних величин. Імітаційну модель про інфрачервоного зв'язку подано відкритою одноканальною системою масового обслуговування. Транзакт, що є неподільним об'єктом в системі імітаційного моделювання загального призначення, породжується бітом, що переміщається в інфрачервоній мережі від джерела інформації до споживача. Модель, за класифікацією є моделлю, G/M/1 з дисципліною FIFO. Час затримки бітів в каналах передавання (Wчерги) даної системи буде визначатись у відповідності до формули до формули для обчислення часу затримки в черзі одноканального пристрою з очікуванням [7-10]:

$$
W_{\text {черги }}=\frac{L_{\text {черги }}}{\sum_{i=1}^{N} \lambda_{i}\left(1-P_{N}\right)},
$$

де Lчерги - середня кількість бітів, що передаються, визначається за наступною формулою:

$$
L_{\text {черги }}=\sum_{i=1}^{N} n P_{n},
$$

де $P n$ - імовірність того, що в каналі інфрачервоного передавання даних знаходиться $n$ бітів і визначається за формулою:

$$
P_{n}=P_{0} \sum_{i=1}^{N} \rho_{i}{ }^{n},
$$

$P_{0}$ - імовірність того, що підканал на даний момент зайнятий, визначається за формулою:

$$
P_{0}=\frac{1-\sum_{i=1}^{N} \rho_{i}{ }^{n}}{1-\sum_{i=1}^{N} \rho_{i}{ }^{(n+1)}},
$$

де $\rho$ - навантаження на мережу бездротового передавання даних, що визначається за формулою (2). Підставивши дані значення у формулу (3), отримаємо наступну результуючу формулу:

$$
W_{\text {черги }}=\frac{\sum_{n=0}^{N} n \frac{1-\frac{\sum_{i=1}^{N} \lambda_{i}}{\mu}}{1-\left(\frac{\sum_{i=1}^{N} \lambda_{i}}{\mu}\right)^{(N+1)}}\left(\frac{\sum_{i=1}^{N} \lambda_{i}}{\mu}\right)^{n}}{\sum_{i=1}^{N} \lambda_{i}\left(1-P_{N}\right)} .
$$


У результаті моделювання були отримані параметри роботи мережі, зокрема затримка в чергах каналів передавання обох пристроїв,що відповідає пропускній спроможності каналу передавання у випадку, коли навантаження на даний канал є максимальним [6].

Досліджено стандарти мережі типу IEEE 802.11, застосовуючи ту чи іншу дисципліну черг, що задається за допомогою застосування одного з алгоритмів управління чергами. Основною задачею даних досліджень являється моделювання багатоканальної безпроводової сенсорної мережі передавання даних вимірювання, із застосуванням різних алгоритмів управління чергами. Визначення на практиці оптимального алгоритму управління передавання даних, за допомогою проведення порівняльних характеристик. Алгоритми, що застосовуються для моделювання беруться довільно [7-10].

Алгоритми управління чергами потрібні для роботи в періоди тимчасових перевантажень при максимальному завантаженні каналів передавання безпроводової мережі, що знаходиться у складі комп'ютеризованої системи вимірювання механічних величин, якщо мережевий пристрій не може впоратися 3 передаванням бітів на вихідний інтерфейс в тому темпі, в якому вони поступають. Якщо причиною перевантаження є недостатня продуктивність процесорного блоку мережевого пристрою безпроводової, то необроблені біти тимчасово накопичуються у вхідній черзі відповідного вхідного інтерфейсу. Черг до вхідного інтерфейсу може бути декілька, якщо диференціюються запити на обслуговування по декількох класах. У тому ж випадку, коли причина перевантаження полягає в обмеженій пропускній спроможності вихідного інтерфейсу, біти тимчасово зберігаються у вихідній черзі (або чергах) цього інтерфейсу. Концептуальні моделі мереж з застосуванням різних алгоритмів управління чергами в мережах WI-FI представлені відкритою багатофазною системою масового обслуговування. Кожна фаза моделювалася CMO $G|M| n$ побудована згідно умов того чи іншого алгоритму управління чергами. Результуючою формулою для визначення часу затримки бітів в каналах передавання (Wчергu) даної мережі буде формула 1 тому, що модель даної мережі також представлена у вигляді багатоканальної СМО з очікуванням. Модель складається з вимірювальних сенсорів та точки безпроводового доступу. Опишемо роботу даної системи: біти, що надходять з сенсору, який передає дані вимірювання, стають у чергу на обслуговування д точки доступу. Далі у точці доступу, вони стають в чергу на розподілення до робочих станцій, які $\epsilon$ їхніми адресатами. Потім вони стають у чергу на обробку до потрібного адресату [7-10].

Розглянуто 3 моделі відповідної структури у яких застосовувались 3 різні алгоритми управління трафіком, що застосовуються у різних стандартах IEEE 802.11, а саме «FIFO», «Пріоритетне обслуговування», «Зважені черги». Проведене дослідження з метою порівняльної характеристики між цими алгоритмами за критеріями пропускної спроможності каналів передавання, максимальної швидкості передавання показників, дальності передавання показників, кількості підканалів. Після ряду досліджень з метою порівняння, проведених за правилами процедури підтримки прийняття рішень “Analityc hierarchy process" (AHP) по даним алгоритмам було отримано наступні підсумкові коефіцієнти, а саме алгоритм «FIFO»- 0,228, алгоритм «пріоритетне обслуговування»- 0,222, алгоритм «Зважені черги» - 0,55. У результаті даних порівнянь досліджено, що алгоритм «зважені черги» в двічі кращий ніж 2 інших. Проведено дослідження, які показали, що результати, отримані при використанні моделі типу $G / M / n$ для моделювання передачі показників вимірювання сенсорними мережами, $\epsilon$ найбільш точними серед інших моделей.

Досліджено модель сенсорної мережі на концептуальному рівні. На основі результатів моделювання даної мережі при стандартній смузі частот мережі “Bluetooth” (2400 - 2483,5 МГц ISM-діапазону), за формулою (1) була одержана характеристика на рис. 1 [7-10].

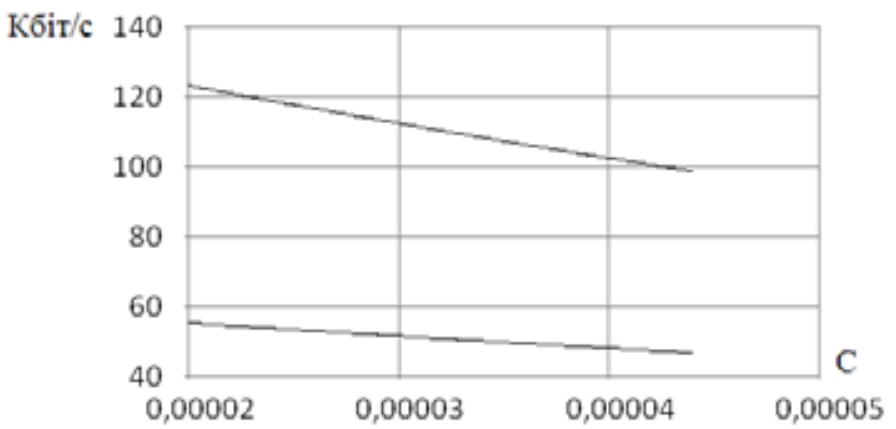

Рис. 1. Графік залежності пропускної спроможності каналу передавання від часу затримки на обробку 
Стандартну смугу частот було розширено на 80 МГц, та за формулою (1), знято характеристику, що на рис. 2.

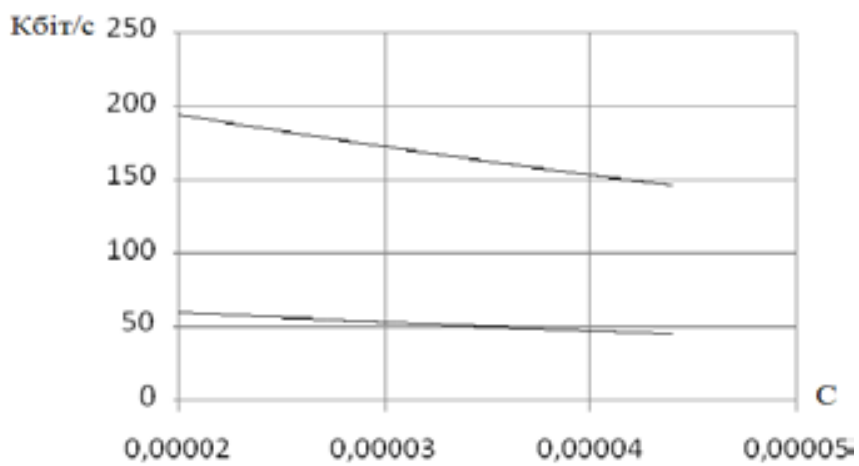

Рис. 2. Графік залежності пропускної спроможності каналу передавання від часу затримки на оборобку при розширенні смуги частот

У підсумку зроблений висновок, що розширення смуги частот хоч і погіршує на початку швидкісні показники передавання показників вимірювання сенсорною мережею Bluetooth, але значно поліпшує інші параметри, зокрема пропускну спроможність.

Досліджено інфрачервону сенсорну мережу. Передавання показників вимірювання, в даному випадку, буде відбуватися від одного вимірювального пристрою до іншого. Досліджено залежність пропускної спроможності каналу передавання $(C)$ від часу затримки на обробку в обслуговуючому пристрої каналу, яку зображено на рис. 3, було одержано за формулою (3) [7-10].

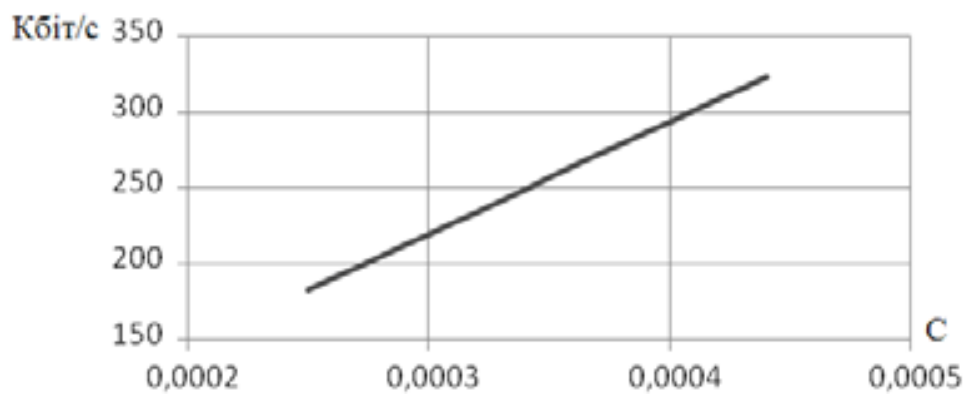

Рис. 3. Графік Залежності пропускної спроможності каналу передавання від часу затримки на обробку в обслуговуючому пристрої каналу

На даному графіку спостерігається лінійне зростання навантаження. Що свідчить про стабільну поведінку обслуговуючих пристроїв при моделюванні стаціонарних процесів за допомогою моделей типу $G / M / 1$.

Запропоновано алгоритм функціонального об'єднання нижніх рівнів еталонної моделі OSI.

Дану технологію було застосовано для досліджень мереж стандарту IEEE 802.11 із застосуванням трьох вищезазначених алгоритмів. Це дало змогу одержати наступні результати, за формулою 5, що зображені на рис. $6,7$.

Алгоритм базується на контролюванні бітів фрейму фізичного рівня. Він побудований з тою метою, щоб з полів фрейму, які містять інформацію про середовище передавання даних, отримувати потрібну інформацію. У даному методі мережевий рівень через певні проміжки часу відсилає запити на фізичний про стан сигналу на даний момент. Інформація про стан сигналу міститься у полі, в якому перші біти тримають у собі інформацію про швидкість передавання, а інші про стан сигналу [7-10].

Зазвичай кожному з вище перелічених станів сигналу відповідає число від 0 до 6. На основі одержаних даних мережевий рівень формує уявлення про зміну станів зв'язку, постійно порівнюючи теперішній та попередній стани $\left(n<n_{0}\right.$ чи $\left.n \geq n_{0}\right)$. У випадку, коли зміна станів відповідає $n<n_{0}$, мережевий рівень відсилає повторний запит. Даний цикл буде відбуватися до тих пір, доки ситуація не стане протилежною $\left(n \geq n_{0}\right)$ (гілка «так»). Лише тоді мережевий рівень направить до канального пакет і віддасть 
наказ на його передавання. Потім канальний рівень, при наявності вільного каналу, надасть наказ на генерацію бітів фізичному рівню, у відповідності до конкретного пакету [7-10].

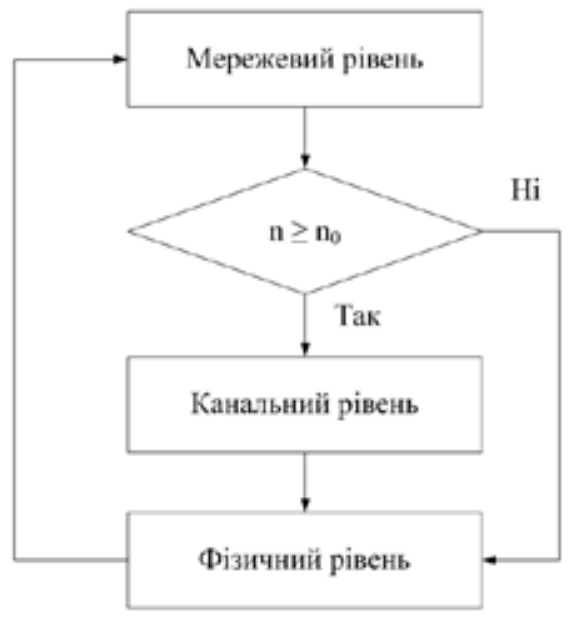

Рис. 4. Блок-схема алгоритму аналізу стану якості сигналу

Особливості даного алгоритму було враховано в структурній схему пристрою безпроводового передавання даних лінії, що виконувала б функцію зв'язку між додатками фізичного та мережевого рівнів еталонної моделі OSI. Тобто працювала б на основі даного алгоритму. Саме з цієї причини в існуючу структурну схему пристрою безпроводового зв'язку вводиться аналізатор якості сигналу 5 рис. 5.

При побудові пристрою, блоки розбито на модулі, згідно їхньої належності до того чи іншого рівня еталонної моделі. Пристрій містить керуючий блок 1, що є частиною $N M S$, модулю мережевого рівня 2, модуль підрівня $L L C$ канального рівня моделі 3, блоку хост інтерфейсу 3.1, вбудованого мікроконтролера 3.2 , блоку додатку прийомо/передавача 3.3, блоку шинного інтерфейсу 3.4, пам'яті S, модулю підрівня $M A C$ канального рівня 4, контролера смуги частот 4.1, радіочастотного прийомо/передавача 4.2, аналізатора сигналу 5, модуля фізичного рівня 6, інтерфейсу фізичного рівня 6.1, антени 6.2., блоку автоматичного налаштування частоти 7.

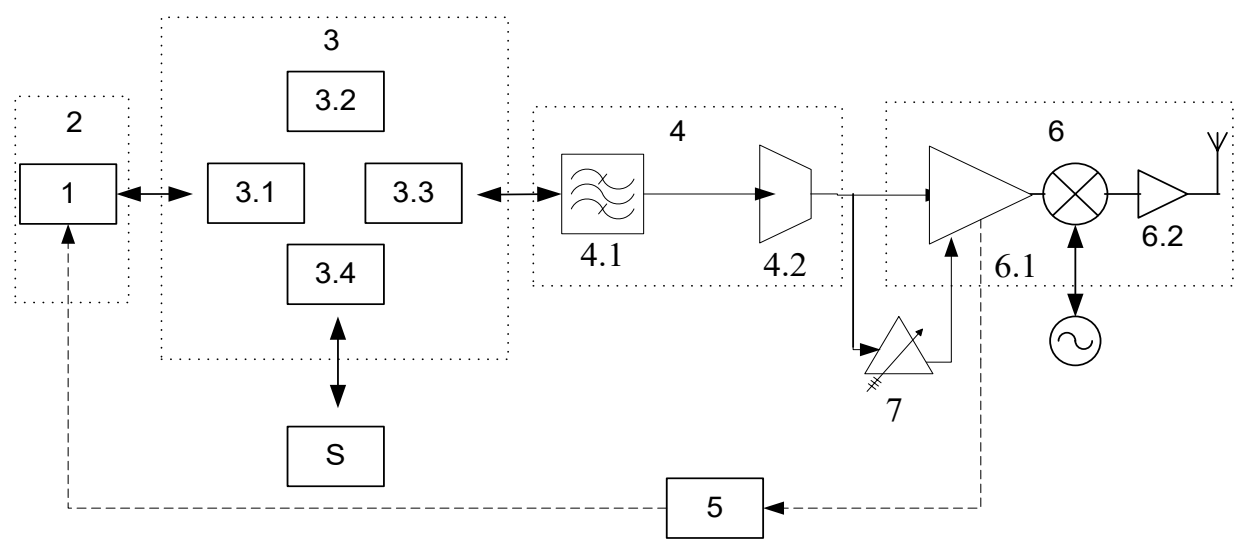

Рис. 5. Безпроводовий мережевий пристрій з системою підвищення якості передачі показників вимірювання в зонах невпевненого прийому або з недостатньою завадостійкістю

Точка насичення $X_{0}$ визначається за формулою:

$$
X_{0}=\frac{1}{V_{d} R_{d}}
$$

де $X_{o}$ - найбільше навантаження для даної мережі;

$V d$ - коефіцієнт відвідування для вузла $d$;

$R d$ - час перебування бітів у мережі для вузла $d$. 


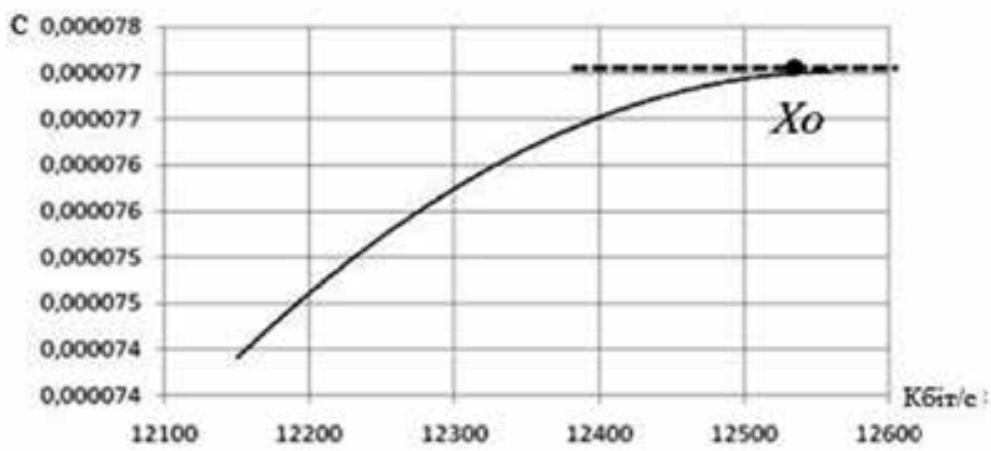

Рис. 6. Графік залежності часу затримки від навантаження каналу передавання

Швидкість передавання показників вимірювання, яку було використано при моделювання відповідала Peak Cell Rate (PCR) - максимальній швидкості передавання даних складає 54 Мбіт/с.

В безпроводових каналах передавання даної мережі перерозподіл потоків буде відбуватися за допомогою алгоритму курування чергами «Зважені черги». Тобто розподіл бітів інформації в каналах передавання буде відбуватись згідно відсотку пропускної спроможності, яка надана даному класу трафіку. Кількість відсотків пропускної спроможності надається тому чи іншому класу трафіку згідно його пріоритету.

Проведено експеримент, згідно згаданого вище алгоритму.

На основі даних досліджень, за формулою (1), було одержано характеристику наведену на рис. 6.

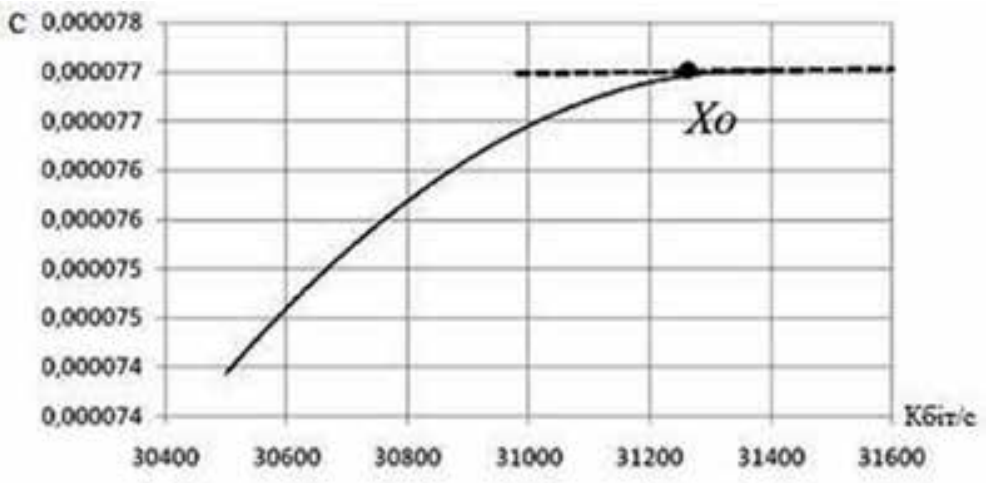

Рис. 7. Графік залежності часу затримки від навантаження каналу передавання

Як показано на графіку, даний алгоритм вносить в роботу безпроводової сенсорної мережі досить позитивні зміни. Це видно з того, що при значному зростанні навантаження в каналах передавання час затримки бітів в черзі на обробку майже не змінився. Тобто дані алгоритми більше майже в три рази покращують швидкісні показники роботи мережі. Цілком імовірно, що таким покращенням сприяє зменшення відсотку помилкових пакетів та запитів на їх повторну відправку, що також потребують певного часу для обробки, а також перехід на стандарт з більшою потужністю при падінні рівня сигналу, що безумовно покращує стійкість роботи сенсорної мережі, значно зменшуючи імовірність відсутності сигналу в зонах невпевненого прийому.

Висновки. Головною особливістю способів управління передаванням даних бездротових інформаційно-вимірювальних систем являється обмеженість пропускної спроможності системи та необмежений вплив перешкод на середовище передавання даних від сторонніх джерел, що випромінюють надвисокі частоти. Можливе зниження пропускної спроможності мережі може сягнути $90 \%$ у порівнянні 3 аналогічним випадком у мережах на основі кабелю.

Моделювання алгоритмів управління чергами безпроводових IBC дозволило виявити те що при використанні алгоритмі «Зважені черги» сумарна пропускна спроможність на 9 Мбіт/с краща ніж при використання інших алгоритмів.

Знайдено наступні рішення проблеми покращення кількісних та якісних показників безпроводового передавання показників відмірювання механічних величин: розширення частотного діапазону 
мережі короткого радіусу дії дає змогу покращити пропускну спроможність мережі майже на 50 \%; запропоновано метод підвищення продуктивності для безпроводових сенсорних мереж, що функціонально об’єднує фізичний та мережевий рівні, що може покращити пропускну спроможність мережі в зонах невпевненого прийому майже в два рази; алгоритм зваженого обслуговування заявок трафіку безпроводових комп'ютеризованих систем вимірювання механічних величин, є найбільш ефективною технологією передавання даних у безпроводових сенсорних мережах, за умови рівня неточності вихідних даних 0,9 та на його основі запропоновано метод «Перерозподіл пропускної спроможності каналу передавання сенсорної мережі», що покращує дисципліну обслуговування в черзі, який буде описано в наступних роботах.

\section{Список використаних джерел:}

1. Квасніков В.П., Хаейн Т.М. Концепція повірки координатно- вимірювальних машин через Інтернет. Методологія та прилади. 2013. № 6. C. 48-53. URL: http://ua.amu.in.ua/journal1.

2. Квасніков В.П., Ганєва Т.І. Нова методика розрахунку датчика деформації. Вимірювальна та обчислювальна техніка в технологічних процесах. 2015. № 3(52). С. 169-173. URL: http://inmad.vntu.edu.ua/portal/ static/41E185F3-5121-491D-84A7-F1E92DE5FB6E.pdf.

3. Kvasnikov V.P., Ganeva T.I. Method of measurement of stress in loaded structures. Metallurgical and Mining Industry. 2015. № 7. P. 340-343.

4. Квасніков В.П., Лещенко Ю.П. Розробка та дослідження інтелектуальної системи для аналізу ймовірнісних характеристик випадкових процесів механічних величин. Технологический аудит и резервы производства. 2015. № 5/3(25). C. 100-102. URL: http://journals.uran.ua/tarp/article/viewFile/52011/48196.

5. Квасников В.П., Орнатский Д.П., Осмоловский А.И. Оптимизация аналогового интерфейса информационно-измерительных систем для дистанционных измерений механических величин. Восточно-Европейский журнал передовых технологий. 2014. № 4(70). С. 31-37. URL: http://cyberleninka.ru/article/n/optimizatsiya-analogovogointerfeysa-informatsionno-izmeritelnyh-sistem-dlya-distantsionnyh-izmereniy-mehanicheskih-velichin.

6. Дуднік А.С. Метод застосування сучасних безпроводових технологій в інформаційних економічних системах. Проблеми та перспективи розвитку економічної кібернетики : монографія / під ред. Т.І. Олешко. Київ : ВД ТОВ «Agrar Media Group», 2013. C. 214-225.

7. Дуднік А.С., Бондаренко Ю.В. Система покращеного передавання даних безпрводових комп'ютерних мереж стандарту IEEE 802.11. Наука і молодь : зб. наук. праць. Київ : НАУ, 2012. № 11(12). С. 113-116.

8. Дуднік А.С., Шевцова Є.В., Зубарєва 0.0. Спосіб підвищення продуктивності безпрводових комп'ютерних мереж на основі міжрівневої взаємодії та пристрій для його реалізації. Проблеми інформатизації та управління : зб. наук. Праць, 2011. № 4(36). С. 45-50.

9. Дуднік А.С., Шевцова Є.В., Яценко М.М., Зубарева 0.0. Пристрій підвищення якості передавання даних в бездротових мережах в зонах невпевненого прийому або з недостатньою завадостійкістю. Пат. № 60400 України, МПК Н04В 7/005; № и201007469; Заявл. 15.06.10; Опубл. 25.06.11. Бюл. № 12.4 с.

10. Дуднік А.С. Динамічний алгоритм управління перерозподілом мережевого трафіку в безпроводових інформаційних системах. Проблеми модернізації України : тези допов. всеукраїнської наук-практ. конф. (м. Київ, 12 листопада 2015 р.) Київ, 2015. С. 126.

\section{References:}

1. Kvasnikov, V.P., Khaeyn, T.M. (2013). Kontseptsiya povirky koordynatno-vymiryuval'nykh mashyn cherez Internet [The concept of calibration of coordinate measuring machines via the Internet]. Metrolohiya ta prylady, no. 6, pp. 48-53. URL: http://ua.amu.in.ua/journal1 [in Ukrainian].

2. Kvasnikov, V.P., Hanyeva, T.I. (2015). Nova metodyka rozrakhunku datchyka deformatsiy [A new method of calculating the deformation sensor]. Vymiryuval'na ta obchyslyuval'na tekhnika v tekhnolohichnykh protsesakh, no. 3(52), pp. 169-173. URL: http://inmad.vntu.edu.ua/portal/static/41E185F3-5121-491D-84A7-F1E92DE5FB6E.pdf [in Ukrainian].

3. Kvasnikov, V.P., Ganeva, T.I. (2015). Method of measurement of stress in loaded structures. Metallurgical and Mining Industry, no. 7, pp. 340-343 [in English].

4. Kvasnikov, V.P., Leshchenko, Yu.P. (2015). Rozrobka ta doslidzhennya intelektual'noyi systemy dlya analizu ymovirnisnykh kharakterystyk vypadkovykh protsesiv mekhanichnykh velychyn [Development and research of an intelligent system for the analysis of probabilistic characteristics of random processes of mechanical quantities]. Tehnologicheskij audit i rezervy proizvodstva, no. 5/3(25), pp. 100-102. URL: http://journals.uran.ua/tarp/article/ viewFile/52011/48196 [in Ukrainian].

5. Ornatskij, D.P., Kvasnikov, V.P., Osmolovskij, A.I. (2014). Optimizaciya analogovogo interfejsa informacionnoizmeritelnyh sistem dlya distancionnyh izmerenij mehanicheskih velichin [Optimization of the analog interface of information-measuring systems for remote measurements of mechanical quantities]. Vostochno-Evropejskij zhurnal peredovyh tehnologij, no. 4(70), pp. 31-37. URL: http://cyberleninka.ru/article/n/optimizatsiya-analogovogo-interfeysainformatsionno-izmeritelnyh-sistem-dlya-distantsionnyh-izmereniy-mehanicheskih-velichin [in Russian].

6. Dudnik, A.S. (2013). Metod zastosuvannia suchasnykh bezprovodovykh tekhnolohii $\mathrm{v}$ informatsiinykh ekonomichnykh systemakh [Method of application of modern wireless technologies in information economic systems]. Problemy ta perspektyvy rozvytku ekonomichnoi kibernetyky : monohrafiia / pid red. T.I. Oleshko. Kyiv: VD TOV «Agrar Media Group», pp. 214-225 [in Ukrainian]. 
7. Dudnik, A.S., Bondarenko, Yu.V. (2012). Systema pokrashchenoho peredavannia danykh bezprvodovykh kompiuternykh merezh standartu IEEE 802.11 [IEEE 802.11 Wireless Wireless Computer Networking System]. Nauka $i$ molod: zb. nauk. prats. Kyiv: NAU, no. 11(12), pp. 113-116 [in Ukrainian].

8. Dudnik, A.S., Shevtsova, Ye.V., Zubarieva, 0.0. (2011). Sposib pidvyshchennia produktyvnosti bezprvodovykh kompiuternykh merezh na osnovi mizhrivnevoi vzaiemodii ta prystrii dlia yoho realizatsii [Method of increasing productivity of wireless computer networks on the basis of interlevel interaction and device for its implementation]. Problemy informatyzatsii ta upravlinnia: zb. nauk. Prats, no. 4(36), pp. 45-50 [in Ukrainian].

9. Dudnik, A.S., Shevtsova, Ye.V., Yatsenko, M.M., Zubareva, 0.0. (2011). Prystrii pidvyshchennia yakosti peredavannia danykh $\mathrm{v}$ bezdrotovykh merezhakh $\mathrm{v}$ zonakh nevpevnenoho pryiomu abo $\mathrm{z}$ nedostatnoiu zavadostiikistiu [Device for improving data transmission quality in wireless networks in areas of uncertain reception or with insufficient noise immunity]. Pat. № 60400 Ukrainy, MPK N04V 7/005; № u201007469; Zaiavl. 15.06.10; Opubl. 25.06.11. Biul, no. 12, 4 p. [in Ukrainian].

10. Dudnik, A.S. (2015). Dynamichnyi alhorytm upravlinnia pererozpodilom merezhevoho trafiku v bezprovodovykh informatsiinykh systemakh [Dynamic algorithm for controlling the redistribution of network traffic in wireless information systems]. Problemy modernizatsii Ukrainy: tezy dopov. vseukrainskoi nauk.-prakt. konf., m. Kyiv, 12 lystopada 2015 r. Kyiv, p. 126. [in Ukrainian]. 